\title{
Effect of Epidermal Growth Factor on Osteosarcoma Cell Proliferation and $\mathrm{Bcl}-2$ Gene Expression
}

\author{
(D) Ayla Solmaz Avcıkurt1, (D) Eren Altun² \\ ${ }_{1}^{1}$ Balıkesir University Faculty of Medicine, Department of Medical Biology, Balıkesir, Turkey \\ ${ }^{2}$ Balıkesir University Faculty of Medicine, Department of Medical Pathology, Balıkesir, Turkey
}

\section{Abstract}

Objective: The aim of this study was to investigate the effects of epidermal growth factor (EGF) on osteosarcoma cell proliferation and Bcl-2 expression.

Methods: In this study, MTT test was first applied to determine the effect of EGF on cell proliferation. Twenty ng/ $\mathrm{LL}$ EGF was added to the Saos-2 cell line and the effects on cell proliferation were determined after different incubation intervals. At the next experimental stage, $20 \mathrm{ng} / \mathrm{mL}$ EGF was added to the osteosarcoma cell line and the expression of antiapoptotic Bcl-2 was evaluated at 1-, 3-, 24-, 48- and 72-hour.

Results: A statistically significant increase in cell proliferation was observed at 3-, 24- and 72-hour after administration of $20 \mathrm{ng} / \mathrm{\mu L}$ EGF in the osteosarcoma cell line. EGF was observed to stimulate Bcl-2 expression at a dose of $20 \mathrm{ng} / \mathrm{mL}$ at 1- and 24-hour.

Conclusion: EGF; at the $3^{\text {rd }}, 24^{\text {th }}$ and $72^{\text {nd }}$ hours, a statistically significant increase in cell proliferation was observed. In addition, the expression of antiapoptotic Bcl-2 was evaluated at the $1^{\text {st }}, 3^{\text {rd }}, 24^{\text {th }}, 48^{\text {th }}$ and $72^{\text {th }}$ hours on the EGF osteosarcoma cell line. The expression of Bcl-2 was increased at the end of the $1^{\text {st }}$ and $24^{\text {th }}$ hours of application of EGF at $20 \mathrm{ng} / \mathrm{mL}$ dose.

Keywords: Epidermal growth factor, Bcl-2, osteosarcoma

\section{INTRODUCTION}

Osteosarcoma (OS) is a malignant mesenchymal tumor associated with the formation of mineralized or non-mineralized bone. OS is the most common primary malignant bone tumor and is mostly seen in young adults and adolescents (1). Apoptosis is a genetically regulated cell death that controls the development of tissues by eliminating physiologically unnecessary abnormal cells (2). Studies focusing on genes and signals that regulate apoptosis play an important role in basic oncology research (3). Chemotherapeutics destroy tumor cells and do so primarily by promoting tumor cell apoptosis (4). Understanding that apoptosis is a gene-directed program has profound effects on developmental biology and tissue homeostasis $(5,6)$. The $\mathrm{BCl}-2$ gene family is the key regulator of apoptosis. The gene group containing $\mathrm{BCl}-2$ and $\mathrm{BCl}-\mathrm{xL}$ has anti-apoptotic activity. The second group of proteins such as Bax or Bim promotes cell death and has pro-apoptotic activity $(7,8)$. Epidermal growth factor (EGF) is a 53-amino-acid peptide that is encoded by a $4.8 \mathrm{~kb}$ mRNA transcript from a gene that is $110 \mathrm{~kb}$ in length, contains 24 exons, and is located on human chromosome $4 q 25$. Like other members of this peptide family, EGF is initially synthesized as a prepropeptide of 1217 amino acids. Members of this family include pre-pro-EGF molecule, a hydrophobic signal peptide, and a transmembrane domain (9). EGF, which acts as a potent mitogenic factor that plays an important role in the growth, proliferation and differentiation of many countless cell types, is a protein that acts by binding to its receptor with high affinity.

The aim of this study was to investigate the effects of EGF on cell proliferation and $\mathrm{BCl}-2$ expression in the human OS model Saos-2 cell line at different time intervals of 1-, 3-, 24-, 48- and 72-hour. 


\section{METHODS}

\section{Materials}

The human OS cell line Saos-2 was obtained from European Collection of Animal Cell Cultures. EGF was purchased from PeproTech. All cell culture material and materials were purchased from Greiner or Gibco.

\section{Cell Culture and Epidermal Growth Factor Applications}

Human OS cell line (Saos-2) cells were grown in a $\mathrm{CO}_{2}$ oven at $37{ }^{\circ} \mathrm{C}$ in an atmosphere of $5 \% \mathrm{CO}_{2}$. Fifteen $\mathrm{ml}$ of Dulbecco's Modified Eagle Medium (DMEM) containing 10\% heat inactivated fetal calf serum (FCS), 100 units/mL penicillin, $10 \mu \mathrm{g} / \mathrm{mL}$ streptomycin and $0.2 \mathrm{mM}$ L-glutamine were used as food medium. Incubation was performed at 1-, 3-, 24-, 48- and 72hour with $20 \mathrm{ng} / \mathrm{mL}$ administration. Total RNA was isolated from the cells at the end of the period.

\section{Establishment of Cytotoxicity Tests and MTT Test}

When the cells grown in a $75 \mathrm{~cm}^{2}$ flask in $15 \mathrm{~mL}$ medium covered the $80-85 \%$ of flask surface, the medium was removed and the cells were washed twice with sterile PBS. Four $\mathrm{mL}$ of trypsinEDTA was added to the flask. It was incubated for 5 minutes in a $\mathrm{CO}_{2}$ incubator. When cells were separated from the surface, medium was added to neutralize trypsin-EDTA. The cells were precipitated by centrifugation at $1000 \mathrm{rpm}$ for 5 minutes, the supernatant was removed and the pellet was thawed with 10 $\mathrm{mL}$ of medium. The number of viable cells in the suspension was determined by trypan blue staining and seeded in a 96 well plate with 5000 cells per well. DMEM medium containing $10 \%$ FCS was added to each well to a final volume of $200 \mu \mathrm{L}$. After cell seeding was completed, the cells were incubated in a $\mathrm{CO}_{2}$ incubator for 24 hours. At the end of 24 hours, EGF was administered at a dose of $20 \mathrm{ng} / \mathrm{mL}$. MTT test was performed at 1-, 3-, 24-, 48- and 72-hour, and absorbance was taken at 550 $\mathrm{nm}$. The MTT method is based on the ability of viable cells to transform MTT (a tetrazolium salt) into formazan crystals. It is one of the most commonly used methods for measuring cell cytotoxicity, proliferation and viability. According to this method, after the desired incubation period (1-, 3-, 24-, 48- and 72-hour), the stock MTT solution is added to the medium where the final concentration determined as a result of the optimization is 0.5 $\mathrm{mg} / \mathrm{mL}$ and it is incubated for 4 hours at $37{ }^{\circ} \mathrm{C}$ in a medium containing $5 \% \mathrm{CO}_{2}$. At the end of the incubation, the medium containing MTT solution is discarded, the crystals are dissolved with isopropanol containing $0.004 \mathrm{M} \mathrm{HCl}$ and absorbance is taken at $550 \mathrm{~nm}$ wavelength with UV spectrophotometer.

\section{cDNA Synthesis}

Total RNA isolation was performed using RNeasy total RNA isolation kit (Qiagen). cDNA synthesis was performed from the isolated total RNA. Briefly, $1 \mu \mathrm{L}$ random primer and $1 \mu \mathrm{g}$ total RNA was mixed. Distilled water was added to complete the final volume to $10 \mu \mathrm{L}$. This mixture was incubated for 10 minutes at $70{ }^{\circ} \mathrm{C}$ and then on ice, $5 \times$ Moloney murine leukaemia virus (MMLV) buffer, dNTP mixture (10 mM each; dATP, dGTP, dTTP and $\mathrm{d}(T P)$, RNase inhibitor (RNasin) and MMLV reverse transcriptase enzyme was added and incubated at $42{ }^{\circ} \mathrm{C}$ for 50 minutes. The synthesized cDNAs were stored in the refrigerator at $-20^{\circ} \mathrm{C}$.

\section{Realtime Polymerase Chain Reaction}

These studies were performed using the applied biosystems 7500 fast instrument. Five $\mu \mathrm{L}$ master mix, $1 \mu \mathrm{L}$ cDNA, $100 \mathrm{ng} / \mu \mathrm{L} 0.5 \mu \mathrm{L}$ forward and reverse primers, $3 \mu \mathrm{L}$ distilled $\mathrm{H}_{2} \mathrm{O}$ were mixed and final volume was completed to $10 \mu \mathrm{L}$. Each cDNA was studied with $\mathrm{BCl}$-2 and $\beta$-2-microglobulin genes for normalization with at least three replicates.

\section{Statistical Analysis}

Mean MTT test results and standard deviations were obtained. The absorbance values obtained at each hour were compared with their control group using the Student's t-test. $\mathrm{P} \leq 0.05$ was considered statistically significant. Livak method was applied to evaluate realtime polymerase chain reaction test results. Each of the $\mathrm{CT}$ values obtained for the $\mathrm{BCl}-2$ gene was subtracted from the mean of the human $\beta$-2-microglobulin gene and a base- 2 log square was obtained. The results were divided by the control group and obtained multiples of 1 was statistically evaluated by Minitab (One-way ANOVA). $\mathrm{P} \leq 0.05$ values were considered significant. Ethical permission is not required in this study since as only cell viability was evaluated in cell culture.

Table 1. Mean and standard deviations of absorbance values at 1-, 3-, 24-, 48- and 72-hour of MTT test, and p values (each test group was compared with the control in its own hour interval)

\begin{tabular}{|c|c|c|c|c|c|c|c|c|c|c|}
\hline Group & $\begin{array}{l}\text { NK } \\
(1-h)\end{array}$ & $\begin{array}{l}\text { EGF } \\
(1-h)\end{array}$ & $\begin{array}{l}\text { NK } \\
(3-h)\end{array}$ & $\begin{array}{l}\text { EGF } \\
(3-h)\end{array}$ & $\begin{array}{l}\text { NK } \\
\text { (24-h) }\end{array}$ & $\begin{array}{l}\text { EGF } \\
(24-h)\end{array}$ & $\begin{array}{l}\text { NK } \\
(48-h)\end{array}$ & \begin{tabular}{|l} 
EGF \\
$(48-h)$
\end{tabular} & $\begin{array}{l}\text { NK } \\
\text { (72-h) }\end{array}$ & $\begin{array}{l}\text { EGF } \\
(72-h)\end{array}$ \\
\hline Mean & 0.3451 & 0.4345 & 0.2066 & 0.2581 & 0.2183 & 0.357 & 0.2399 & 0.3173 & 0.1988 & 0.4175 \\
\hline$p$ & - & 0.040 & - & 0.409 & - & 0.040 & - & 0.172 & - & 0.01 \\
\hline
\end{tabular}




\section{RESULTS}

In this study, firstly, MTT test was used to determine the effect of EGF on cell proliferation. Twenty ng/ $\mu$ L EGF was added to the Saos2 cell line and its effects on cell proliferation were determined at different incubation intervals. A statistically significant increase in cell proliferation was observed at 3-, 24- and 72-hour (Table 1). At the next experimental stage, $20 \mathrm{ng} / \mathrm{mL}$ EGF was added to the OS cell line and expression of antiapoptotic Bcl-2 was evaluated at 1-, 3-, 24-, 48- and 72-hour. It was observed that EGF at a dose of $20 \mathrm{ng} / \mathrm{mL}$ increased $\mathrm{Bcl}-2$ expression at 1- and 24-hour (Table 2).

Table 2. Mean, standard deviation and $p$ values of real time polymerase chain reaction

\begin{tabular}{|c|c|c|c|c|c|c|}
\hline Group & NK & 1-hour & 3-hour & 24-hour & 48-hour & 72-hour \\
\hline Mean & 1 & 1.9291 & 1.289 & 3.126 & 0.98 & 0.8797 \\
\hline SD & 0 & 0.2710 & 0.4870 & 0.8393 & 0.6422 & 0.1188 \\
\hline$p$ & - & 0.04 & 0.342 & 0.012 & 0.952 & 0.154 \\
\hline
\end{tabular}

\section{DISCUSSION}

Cancer is the leading cause of death in the world. Some molecules in humans are important in the process of cancer. Some molecules increase cancer while others function to reduce it. Apoptosis is an inherited process of cell death specific to multicellular eukaryotic organisms. It plays a critical role in the destruction of cells damaged by infection, chemical damage, oxidative damage or radiation (10). Molecules that contribute to the apoptosis process contribute to cell survival or preparation for programmed death. The gene family involved in apoptosis is the $\mathrm{BCl}-2$ gene family. There are members of this family that prevent apoptosis (Bcl-2, BcX2, Mcl-1) and lead to apoptosis (Bax, Bak, Bid, Bim, Noxo, Puma). According to the equilibrium in the expression of these members, the cell is directed to apoptosis. $\mathrm{BCl}-2$, which is the first anti-apoptotic member of the $\mathrm{BCl}-2$ gene family, is one of the molecules that inhibit apoptosis (11). If there is any damage to the mechanism of apoptosis, the cells tend to become cancerous (12). Anti-apoptotic Bcl-2 expression is important in the cancer process (13). EGF acts by binding with EGF receptor (EGFR). Signaling with EGFR leads to cell proliferation and differentiation (14). Chandra et al. (15) showed that EGFR signaling increased proliferation and inhibited apoptosis and was important in maintaining the number of osteoprogenitor cells. In the same study, EGF treatment has been shown to significantly increase the number of osteoblasts by regulating the proportion of proliferative and apoptotic osteoprogenitor cells in the bone (15). This signaling increases the proliferation and survival of osteoprogenitor cells and consequently increases the formation of new bone (15).

\section{CONCLUSION}

EGF is thought to increase the progression of various cancers through proliferation, invasion and induction of angiogenesis (16). In this study, the effects of EGF on cell proliferation in Saos2 cell line which is a model of human OS and the expression of antiapoptotic Bcl-2 were investigated. EGF significantly affected cell proliferation at 3-, 24- and 72-hour. EGF increased Bcl-2 expression in the osteosarcoma cell line at 1- and 24-hour of administration. Regarding our results, EGF-regulated $\mathrm{BCl}-2$ expression is found to be critical for the survival of neoplastic cells in the os cell line.

\section{Ethics}

Ethics Committee Approval: Not applicable.

Informed Consent: Not applicable.

Peer-review: External and internal peer-reviewed.

\section{Authorship Contributions}

Surgical and Medical Practices: A.S.A., Concept: A.S.A., Design: A.S.A., Data Collection or Processing A.S.A., Analysis or Interpretation: A.S.A., E.A., Literature Search: E.A., A.S.A., Writing: A.S.A., E.A.

Conflict of Interest: No conflict of interest was declared by the authors.

Financial Disclosure: The authors declared that this study received no financial support.

\section{REFERENCES}

1. Zhang Y, Hu H, Song L, Cai L, Wei R, Jin W. Epirubicin-mediated expression of miR-302b is involved in osteosarcoma apoptosis and cell cycle regulation. Toxicol Lett 2013;222:1-9

2. Liu K, Liu PC, Liu R, Wu X. Dual AO/EB staining to detect apoptosis in osteosarcoma cells compared with flow cytometry. Med Sci Monit Basic Res 2015;21:15-20.

3. Su Z, Yang Z, Xu Y, Chen Y, Yu Q. Apoptosis, autophagy, necroptosis, and cancer metastasis. Mol Cancer 2015:21;14:48.

4. Taraphdar AK, Roy M, Bhattacharya R. Natural products as inducers of apoptosis: Implication for cancer therapy and prevention. Curr Sci 2001;80:1387-96

5. Lowe SW, Lin AW. Apoptosis in cancer. Carcinogenesis 2000;21:485-95.

6. Strasser A, Cory S, Adams JM. Deciphering the rules of programmed cell death to improve therapy of cancer and other diseases. EMBO J 2011;30:3667-83 
7. Moon JH, Sohn SK, Lee MH, Jang JH, Kim K, Jung CW, et al. BCL2 gene polymorphism could predict the treatment outcomes in acute myeloid leukemia patients. Leuk Res 2010;34:166-72.

8. Czabotar PE, Lessene G, Strasser A, Adams JM. Control of apoptosis by the BCL-2 protein family: implications for physiology and therapy. Nat Rev Mol Cell Biol 2014;15:49-63.

9. Salomon DS, Brandt R, Ciardiello F, Normanno N. Epidermal growth factorrelated peptides and their receptors in human malignancies. Crit Rev Oncol Hematol 1995;19:183-232.

10. Anderson MA, Huang D, Roberts A. Targeting BCL2 for the treatment of lymphoid malignancies. Semin Hematol 2014;51:219-27.

11. Yalçın O, Demir FT, Kılıç Al, Kaya H, Kabukçuoğlu F, Altunay IK. Bcl-2: Is it an Easier Way to Differentiate Psoriasis and Eczema? Okmeydanı Tıp Dergisi 2016;32:190-4.
12. Cory S, Adams JM. The Bcl2 family: regulators of the cellular life-or-death switch. Nature reviews. Cancer 2002;9:647.

13. Sarosiek KA, Letai A. Directly targeting the mitochondrial pathway of apoptosis for cancer therapy using BH3 mimetics-recent successes, current challenges and future promise. FEBS J 2016;283:3523-33.

14. Yarım G F, Kazak F. Epidermal Büyüme Faktörü. Kocatepe Vet J 2016;9:21525.

15. Chandra A, Lan S, Zhu J, Siclari VA, Qin L. Epidermal growth factor receptor (EGFR) signaling promotes proliferation and survival in osteoprogenitors by increasing early growth response 2 (EGR2) expression. J Biol Chem 2013;288:20488-98.

16. Guillamo JS, de Boüard S, Valable S, Marteau L, Leuraud P, Marie Y, et al. Molecular mechanisms underlying effects of epidermal growth factor receptor inhibition on invasion, proliferation, and angiogenesis in experimental glioma. Clin Cancer Res 2009;15:3697-704. 